\title{
Characteristics of housing in rural villages: the case northeastern Montenegro
}

\author{
Goran Rajović ${ }^{1, *}$, Jelisavka Bulatović 2, ** \\ ${ }^{1}$ Street Vojvode Stepe 252, Belgrade, Serbia \\ Phone: 0038161/19-24-850 \\ ${ }^{2}$ Technology and Management, College of Textile Design, \\ Street Starine Novaka 20, Belgrade, Serbia \\ Phone: 003861/ 3082651 \\ *,**E-mail address: dkgoran.rajovic@gmail.com , jelisavka.bulatovic@gmail.com
}

\begin{abstract}
The paper analyzes the basic characteristics of housing in rural areas of northeastern Montenegro, based on examples from Berane, Andrejevica and Plav. People in rural areas northeastern of Montenegro are in accordance with their modest lifestyle, built by the simple but functional living quarters. The chronology of the type of housing facilities is differentiated into morphological types of permanent residence: primitive forms of human habitats (dugouts - cave dwellings, semi dugouts); a more perfect forms of habitats (cottage) and contemporary residential facilities. Today, although of old houses in the rural area of northeastern Montenegro is not much else, nevertheless we can realize, what is the national builder was important in their construction. The tendency to revive the good old and functional forms of housing in rural areas of northeastern Montenegro today is fortunately more and more present. More and more people are that want to the existing old house renovation, both in regards to tradition, as well with oneself but appear and new architectural forms, which are inspired by the national architecture. What is required is a symbiosis of positive and negative forms and phenomena, which have to be that, pull out to light the strictly scientific analysis. Functional analysis of accelerated would stylistic synthesis the positive from the past and the negative the present.
\end{abstract}

Keywords: Northeastern Montenegro; rural villages; primitive forms of human habitats; more perfect forms of habitats; modern residential facilities

\section{INTRODUCTION}

Generally, the about development of two housing in Montenegro, a lot has been written and much is known. It is assumed that such material has sufficiently processed, studied and published in the literature. But on a more thorough analysis, especially in rural settlements and Montenegro through the development trend in housing is an insufficient treated area. Some rural settlements Montenegro as remote spot, mountain, economic backward and burdened with the problems settlements, as well as rural settlements of northeastern Montenegro, are not only sufficient, but only partially treated from the standpoint of specifics housing and elements that differ in important ways from most other settlements in Montenegro [1]. 
On several occasions and in many studies which dealt with economic revitalization and reactivation of rural settlements of northeastern in Montenegro, emphasize the need at the same time the investment and belief in possibility of renewal, and really move in a healthy market economy. Until the moment of writing of this text, it is not only that did not happen, than there is no indication that it will to happen in the near future [2].

The chronology of the type of housing facilities and ancillary farm buildings in rural areas of northeastern in Montenegro is differentiated into morphological types of permanent residence: primitive forms of human habitats (dugouts - cave dwellings, semi-dugouts), a more perfect forms of habitats (cottage) and a modern residential facilities.

The tendency to revive the good old and functional forms of housing in rural areas of northeastern in Montenegro today is fortunately more and more present. More and more people are who want to the existing old house renovation, as well as with the tradition and with themselves, but there are also new architectural forms that are inspired rural architecture. However, to order to avoid merely replication of form, it is very important that you take the solution which is a proven builder of rural the wisdom. Of course one should not forget the natural materials that are so carefully chose the old builders and which was the basis for the construction of a pleasant and functional residential houses [3].

What are still being planned and built up, should carry characteristic of locations, because time is so that they must think about of rationality and smaller investment, and in order to provide more, better example of the construction of our ancestors does not exist. They are subtle feeling knew how to combine exceptional functionality, to exercise enviable constructive interventions, and that the in doing so attain design of attracts and does not offend the environment. The harmony that our ancestors achieved with nature, is rarely is dating and realizes in the present [4].

\section{RESEARCH METHODOLOGY}

The core methodological procedure used in this study is geographically (spatial) method. Thus, the study of geographical method was related to rural settlements of northeastern in Montenegro [5]. Northeastern Montenegro is a geographic unit, which includes $10.8 \%$ of the total area of Montenegro $\left(13,812 \mathrm{~km}^{2}\right)$. It includes three municipalities: Plav, Andrejevica and Berane [6,7]. For of data collection pertaining to basic housing characteristics, we used the comparative method. Permeated through the entire text of the method and of integrity, thanks to which we are able to recognize, define and evaluate potential limitations to development residential of the fund. Historical method gave us the opportunity to perceive the evolution of for housing development in the rural areas of northeastern in Montenegro that is based on historical findings reconstruct time of housing. For of data collection which related to the total number and type of housing, and the equipment of the apartments, plumbing, electric power and ancillary facilities, we used the statistical method. The research methodology is primarily based on an analysis of existing literature on the characteristics of housing in rural areas of northeastern Montenegro. From the existing literature, has been used both domestic and those published in the international literature. On this occasion of the international publications emphasize this: Wiggins and Proctor [8], Primi [9], Mohapatra et al [10], Renkow [11] Lohmann and Liefner [12]. Were studied and written sources on the internet. [13] The scientific explanation of terms, by two methods, namely: analytic and synthetic. Analytical methods have been considered some of the dimensions research subject. A synthetic method is whole of mutual connection between subject and recommended measures that derive there from. 


\section{ANALYSIS AND DISCUSSION}

One of the main goals of every person to life is during the build or design a space in which will live and where they would feel safe and relaxed. The house is because, from the earliest times, was not just a place where a man hiding from the cold, thunder and storms, but also his artistic and spiritual inspiration. People in the rural areas of northeastern Montenegro, in accordance with their humble lifestyle, they built a simple but functional living quarters. Today, although the old houses in the rural area of northeastern Montenegro is not much left, still we can realize what is rural builder was the most important the occasion of their construction.

The development of family homes in rural areas of northeastern Montenegro and its space - functional, constructive and shaped transforming was followed by the laws of evolution, the general socio - economic developments and monitors their economic, cultural and demographic development. As in the past, and today, the socio - economic processes are simultaneously created and developed with the same intensity in all parts of Montenegro, so that development and changes in the manner of living followed the tendencies. Thus in the economically developed areas of Montenegro (who were also demographically stronger and better equipped transport infrastructure), the process of development village houses and residence emerged much earlier and developed more rapidly, than the same in other economic - cultural zones even in rural settlements of northeastern Montenegro. For these reasons, today, in the hilly mountainous villages of northeastern Montenegro may find two part and three parts log cabin, typical of the houses of at the end of the nineteenth century.

Contemporary problems of rural the family house cannot be separated from the problems of organization, planning and construction of rural yard because they are directly or closely related. Improperly is viewed only the house - apartment without his connections with surrounding space and the old and new accompanying and commercial premises (summer kitchen, dairy, cattle barn ...) as well as the natural environment [14]. That is why, as necessary to impose the study of rural housing in rural settlements of northeastern Montenegro in all its forms, which is undoubtedly one of the most important factors of rural dwelling, respectively the study of rural households.

The chronology of the types of housing facilities and ancillary farm buildings in rural settlements of northeastern Montenegro differ is following morphological types of permanent residence:

1. Primitive forms of human habitats (dugouts - cave dwellings, semi-dugouts)

2. More advanced forms of habitat (cottages) and

3. Contemporary housing facilities.

Dugouts - cave dwellings, the oldest forms of human dwellings in rural settlements of northeastern Montenegro. According Cvijić $[15,16]$, is the simplest form of the dugout houses, which allows minimum space and dryness necessary for life. Deroko [17] points out that a man leaving the cave, based shelter themselves grooving. Roter et al [18] indicate that dugouts represent a hole formatted in a the basis of circular, oval or quadrangular, shape, depth across $1.30 \mathrm{~m}$. Roof coverings is a complex in the cup or on a two water. The walls of the dugouts were relining with timber. Dugouts had a temporary character and cannot be attributed to any particular time or people. They are found always at the beginning of the creation of life in the rural settlement northeastern of Montenegro or periods amounting when they expressed great population migrations. 
Semi-pits in rural settlements northeastern Montenegro, were built so that in the land mine dent rectangular shape of $2 \mathrm{~m}$ to $2.5 \mathrm{~m}$, which is the inside of the stone masonry, to prevent rockslides land. Over recess is built roof conic or circular shape so that it relies on the ground. His skeleton is made up of several curves of wood ("head") vaulted at the top. In order construction was stable across the "head" were put thicker wooden binders and riveted wooden pegs - transverse poles. Beyond that, stacked of oak or beech small forest or undergrowth and roof covered rye straw, fastened with "pressing of small wicker". And semi-dugouts are like dugouts had woven wicker doors. Until them are came across a few stairs dug into the ground [19].

Transformation of elements intended for habitation and other infrastructural facilities in rural settlements of northeastern Montenegro can be analyzed from two angles of observation. Changes can be tracked, if the main object of study and consideration of housing take:

a) Construction materials, from which the housing facilities constructed or with their presence dominates the ambient visual experience of the object and

b) The functional structure of the object, or number, interrelationship schedule, purpose, size of the rooms in the dwelling and form dimensions, that they determine their interrelation (Videnović, 1996).

If changes are perceive by the first possible topic, you can see several development phases house in the rural settlements of Montenegro. In the beginning of housing by Vešović [20] and Lutovac [21] are about primitive habitats, when used material that was in hand. It was built the huts of sod and woven wicker. Later is built "house from the circular base in one topic". Who's skeleton of the straw, and roof of straw.

Modification or changes to the way the construction of buildings can be manifested as:

a) Closing of certain housing office or the establishment of new in dwelling,

b) Termination of some old of construction and begin forming part of the house or of objects with new material,

c) Improvement of housing comfort by changing the structure in function, or the introduction of certain installations and equipment in object,

d) The transition from completely manually agrarian - primitive ways of making objects via elaborated partially a unified - artisanal ways to introduction of to the aid mechanization and the use a certain number of prefabricated elements and

e) Upgrade and modification of existing facilities, under the influence of increasing power owner and of subsequent desires [4].

According Rajović [22] "house from the circular base in one topic" construction is obtained sequencing or stacking round logs - from circular base in one thread. Hearth is in the middle of habitats. Width of the input is conditioned by layout and distance between siba. Have no windows. "House from the circular base in one topic" a narrow habitat and its angle at ground are almost unused. The walls dubiroga are plaited wicker and plastered with mud on both sides. "House from the circular base in one topic" rim at a height of one and a half meters placed the shelves for dishes and pouring milk and rimmed "house from the circular base in one topic" hung personal clothing and bedding. In front "house from the circular base in one topic" on logs around was placed flooring (planks) that was used for sitting, in addition to "wire for drying laundry" (beech and fir ropes is set to two pillars which served for drying clothes or bedding washed.

In the second phase of development of the family home residents of rural settlements northeastern of Montenegro, raise housing. They were ordinary housing facilities, are about 
five to six feet, and were built of fir or beech planks. Middle of the house placed the purl in, usually of fir beams, attached to two to three fir or beech pillars. With both sides are stacked flooring (planks), the purl in of the planks (thinner planks) to overlap, also, and houses (two shorter side wall of the house) are made of planks and hold to in absence of nails, beech and fir poles. With what is on one side of the house to the east, built up the door of planks with a wooden keyhole [23].

In the third phase of the population in rural settlements northeastern of Montenegro built chalets - house of the land poorer and wealthier house above the "basement" covered with straw rarely with shingle [20]. Thus, the early nineteenth century, rural settlements in northeastern Montenegro formed in a form that we know today. During this period, the first one-piece construction, a modest home, but as soon as they have gained favorable historical circumstances, the vitality of the people is very fast come to the fore, to begin construction of the two pieces and later the house with many rooms. It is interesting that expansion of space has not changed the relationship of household members towards the initial, central room, which remains are the main part of the house. Custom, to the space and so the extended variants is still called a "house", while other rooms received a new name, the best confirmation its importance for family members. Milovanovic [3] emphasizes that the central room of family members represented a kind of shrine, because everything that was related to the life cycle of a family was going on precisely in this room. In addition to distributing food, it is extremely important gather household members in one place, where they exchanged emotions and spiritual experiences are connected with the fire on the hearth.

One of the main types of houses in the rural settlements of northeastern Montenegro is "log cabin". In rural house this time nothing is superfluous and nothing that is not a function of an ordinary life. They exude harmony between the needs, abilities and desires. Rural builder is the feeling gained just by living in harmony with yourself, and in accordance with the space and the social environment. "A beautiful example that shows how much rural respected builder himself and had a sense of balance is the way that determined the height of the house. None there is no the height, indecent surrounding landscape. They seem to be like they are growing out of it. As a result, that during the construction in every respected measure of a man, "the old house", in spite of adversity, surviving as they are, to this day" [24].

Another possible topic from which is seen economic development (functional structure) by Kojić [25], can be traced from the of time when it starts to get out of the box one premises, called by the people "home" or " house with chimney". Important forms that characterized not infrequently both transformation - from one-piece to two-part, then purely two-part ("house" and room), and three-part and multi-part to a more developed type of house, with four or five departments Another possible topic from which is seen economic development (functional structure) by Kojić [25], can be traced from the of time when it starts to get out of the box one premises, called by the people "home" or "house with chimney". Important forms that characterized not infrequently both transformation - from one-piece to two-part, then purely two-part ("house" and room), and three-part and multi-part to a more developed type of house, with four or five departments.

The selection of materials for the construction of houses in the rural area of northeastern Montenegro depended primarily on the climate. According Lutovac [21] after the Balkan wars, instead of log cabin population raises the house of stone and covered with shingles. The stone was built with moistened land (loam) and mixed with chaff (the rest of the cereal after threshing). Red brick will appear just before the second world war, a roof tiles and concrete elements, occur at the beginning of fifties year the last century. It is known that a man, living in a specific natural environment, aligns with material that has the most environments. 
If you have a stone, man will just go down well the best houses built of this material. Precisely in that adaptation of construction place where there house raises the mirror and skill builders, who remains the faithful to the basic elements of "dinara" house, but the building materials selected from the immediate natural environment. Thus, if the "house" built on steep terrain, usually has a foundation of stone while the walls of logs, the roof structure of wooden beams, and the roof is covered with wooden planks shingles. The central room is in that case monitored slope. In areas where the land is flat house has or the skeletal construction of wooden beams between which the space is filled with wooden planks or wattle, muddy mortar affiliated [3].

The period since World War II until the seventies of the twentieth century is the time restructured a predominantly agrarian to predominantly industrial concept of life and action. Global social efforts were focused on the construction of factories and industrial installation development of cities and public facilities.

In this period, reveals two modes of spatial behavior of people:

a) Traditional, which in addition to from a shift towards a new social - economic relations and industrial methods of production relations remains a thing he lacks in then existing conditions does not increase the material base on which bases its existence and

b) Radical, which terminates the connection with the earth and want to incorporate as much as possible of the new economic - social relations.

According Rajović and Bulatović (2013) the process of depopulation in rural settlements of northeastern Montenegro, in the seventies of the twentieth century, has reached worrying proportions.

The depopulation in areas that include 85 out of 113 settlements, or $72.81 \%\left(1,082 \mathrm{~km}^{2}\right)$, the total area of the region $\left(11.486 \mathrm{~km}^{2}\right)$, according to the census of 1971 , had lived 37.851 people (59.94\% of total population) while 2003 population of 9.578 (17.52\% of the total population). For example, the depopulation of rural settlements expressed in northeastern Montenegro, who could not keep the population amounted to (the index for the period 19712003, settlements: Kurikuće 28.8; Dulipolje 29.0; Seoca 30.0; Bastah 38.5 Kralje 40.3; Gornja Ržanica 45.2 .....). So, how is the process of depopulation has reached scale of that are difficult to stop, thus a number of housing units abandoned and left to the elements and the natural aging.

According to the Statistical Office of Montenegro [26] is the number of abandoned housing in rural settlements of northeastern Montenegro in 2003 has risen to the 312 and covers $15.562 \mathrm{~m}^{2}$. On the other hand, there is the problem a seasonal or occasional use housing units (houses). Those in rural settlements of northeastern Montenegro are 1138 with area of 56.289 $\mathrm{m}^{2}$. Thus, the former permanent residents of rural settlements, only in summer or in winter come and spend some time in mind of vacation or partial housing.

With a global picture of the current status and directions for further thought out and activities of socio-economic and spatial development, in addition to the overall revitalization of rural settlements of the region, it should go in the direction:

a) Protect it from further decay and

b) That housing facilities harness rationally its full extent.

By placing a different economic - social and socio - economic framework in the rural settlements of the region, the existing residential spaces, among others would give the use value and to their use, be expressed as an element of market demand, and items interests occasional users, whether in agricultural or tourism purposes. 
If the size of the existing housing units compared the model with modern apartment or house for habitation, they saw to it that most of the housing in the rural settlements of northeastern Montenegro substandard an, although in recent decades renovated, modernized and adapted to new needs housing. The newest building, size of the units is generally larger and more comfortable and built with the ambitions a seasonal use. It was observed richness space for housing and construction, caused by demographic discharge researched area, as well as significant opportunities revitalization of existing housing stock.

Table 1. Number of housing and area $\mathrm{u} \mathrm{m}^{2}$ in rural settlements of northeastern Montenegro 2003.

\begin{tabular}{|c|c|c|c|c|c|c|}
\hline $\begin{array}{c}\text { Type of } \\
\text { dwellings }\end{array}$ & $\begin{array}{c}\text { Separate } \\
\text { rooms }\end{array}$ & $\begin{array}{c}\text { Studios and } \\
\text { one- } \\
\text { bedroom } \\
\text { apartments }\end{array}$ & $\begin{array}{c}\text { Two- } \\
\text { bedroom } \\
\text { apartment }\end{array}$ & $\begin{array}{c}\text { Three- } \\
\text { room } \\
\text { apartments }\end{array}$ & $\begin{array}{c}\text { Four-room } \\
\text { apartments }\end{array}$ & $\begin{array}{c}\text { Five-room } \\
\text { apartments } \\
\text { and more }\end{array}$ \\
\hline Number & 199 & 2.239 & 3.228 & 3.808 & 2.148 & 820 \\
\hline $\begin{array}{c}\text { Area in } \\
\mathrm{m}^{2}\end{array}$ & 3.259 & 70.185 & 164.331 & 256.477 & 174.068 & 101.711 \\
\hline
\end{tabular}

Source: Statistical Office of Montenegro Census of Population, households and dwellings (appropriate year), the calculation of data by the authors.

Of the total number of dwellings in rural settlements of northeastern Montenegro, as shown in Table 112.340 housing objects with area of $770.133 \mathrm{~m}^{2}$, in separate rooms waste kinds 199 apartments with area of $3.259 \mathrm{~m}^{2}$, studios and one-bedroom apartments come 2.239 apartments with area of $70.185 \mathrm{~m}^{2}$, two-bedroom apartment has 3.228 housing objects with area of $164.331 \mathrm{~m}^{2}$, in three-room apartments housing objects 3.808 comes with area of $256.477 \mathrm{~m}^{2}$, to four-room apartments come 2.148 housing objects with area of $174.068 \mathrm{~m}^{2}$ and five-room apartments and more coming 820 housing objects with area of $101.711 \mathrm{~m}^{2}$.

The lack of certain infrastructure, especially high-quality roads, to a great extent reduces the quality of the housing stock in rural settlements of the region, which along with its other characteristics make the typical image of good part rural settlements in Montenegro.

Not better situation or with indirect capacities that are a function of water supply and supply of power of the population.

How is this situation, at least in terms of water supply, or equipped dwellings with plumbing, electrical power, and ancillary equipped bathroom premises, can be seen from the following table, respectively from Table 2 . 
Table 2. Equipment housing in rural settlements of northeastern Montenegro, plumbing, electrical power and ancillary facilities in 2003.

\begin{tabular}{|c|c|}
\hline \multicolumn{2}{|c|}{ Water supply } \\
\hline Number of dwellings & 9.242 \\
\hline Area in $\mathrm{m}^{2}$ & 617.929 \\
\hline \multicolumn{2}{|c|}{ Electrical power } \\
\hline Number of dwellings & 12.171 \\
\hline Area in $\mathrm{m}^{2}$ & 761.827 \\
\hline \multicolumn{2}{|c|}{ Auxiliary premises - bathroom } \\
\hline Number of dwellings & 7.555 \\
\hline Area in ${ }^{2}$ & 526.919 \\
\hline
\end{tabular}

Source: Statistical Office of Montenegro, Population census, households and dwellings (appropriate year), the calculation of data by the authors.

The data given in this review of 2003 clearly indicate that the percentage of dwellings with water equipping 9.242 dwellings (houses) with area of $617.929 \mathrm{~m}^{2}, 12.171$ electric power apartment with an area of $761,827 \mathrm{~m}^{2}$ and auxiliary rooms - a bathroom with area of $7.555 \mathrm{~m}^{2}$ 526.919 relatively small.

Since the specificity of rural settlements of northeastern Montenegro outstanding quality of the environment, from that point of view is observed remarkable synthesis of complementary economic activities (agriculture and tourism), as well as their ecological character. In this sense, many authors, among which, on this occasion apostrophized (Binford [27], Brown and Bhatti [28], Smith [29], Verhage [30], and LI and LUI [30], Bakić [31], and Bulatović and Rajović [31]) indicate that the incorporation of modern elements into the existing structure should not be avoided, but should apply to be a reflection of our times and our economic opportunities, not to disturb the environment for centuries in harmony and thoughtfully constructed.

Our research evidence based on similar studies Videnović [4], pointed to the forefront when it comes the housing stock in rural settlements of northeastern Montenegro:

a) Continuing the positive trend of permanent and seasonal stay in it, but simultaneous restoration and preservation of traditional values (where the households successfully demographic development and general tendencies resist decay, not affected by the new programs), virtually in this group does not intervenes,

b) The establishing and connecting elements households with a newly formed business objects smaller type (mini farms), where users are employed as carriers of work around agriculture while simultaneously to them enabled expansion of in stages activities

c) Entering into existing habitation and newly created economic capacity "eco" dimension, production with the orientation toward on the principles of "healthy food" - eco agriculture and

d) Expanding activities in the development of "rural" tourism or "ecotourism", where the granting accommodation capacities create the conditions for stay for guests and 
developing new social and economic quality, would reduce emigration from of rural settlements of northeastern Montenegro, and create conditions for the return of immigrant.

Today's modern housing facilities in rural settlements of northeastern Montenegro, the building of modern building materials, with plenty of reinforcement steel, concrete, and mostly hollow clay bricks. The manner of their performance ranges from relatively primitive, oldfashioned arrangement of rooms with a subsequent redrafting, the previously projected and the perceived technical detail solutions.

During the period of economic "boom" in the region are lost identity and a real connection with the homeland. This is partly contributed to the departure of the population of rural settlements northeastern of Montenegro abroad to work abroad and acceptance of aesthetic that is not be appropriate in this area. The mere copying of with which they met the inhabitants of the rural settlements of the region abroad [34], have not only forgotten the value of rural architecture, but also the value of good architecture [3].

Construction of multi-storey house, which was in vogue in rural settlements in northeastern Montenegro in recent decades also, had a lot of practical justification. It is incomprehensible, according to Živković [24], why they built multi-storey building, if a sufficiently large area of for the house on one level, much more comfortable. Like the forgotten one of the essential needs of man who lives in villages, and that the contact with the ground, and there is nothing nicer than stepping on the grass in the morning when leaving the house. Construction of multi-storey house, which was in vogue in rural settlements in northeastern Montenegro in recent decades also, had a lot of practical justification. It is incomprehensible, according to Živković [24], why they built multi-storey building, if a sufficiently large area of for the house on one level, much more comfortable. Like the forgotten one of the essential needs of man who lives in villages, and that the contact with the ground, and there is nothing nicer than stepping on the grass in the morning when leaving the house. If we start from being a person's home should be thus comfortable and projected to provide host more time for a spiritual development, which will depend on the preferences, then new country house certainly does not enable, especially women.

What are still being planned and built up in rural settlements of northeastern Montenegro should bear the hallmark of the site, because the time so it is necessary to consider the rationality and a smaller investment and to provide more, better example of the construction of our ancestors has. They feel the subtle know how to combine exceptional functionality, to achieve remarkable structural interventions, while at the same design of attain which captivates and does not offend the environment. Harmony that our ancestors achieved with nature is rarely seen and realized in the present. Thinking Kojića [25] is the following: it is a symbiosis of positive and negative phenomena and forms which has to be seen to extract on the strictly scientific analysis. Functional analysis would speed up the stylistic synthesis of the positive and negative of the past the present. Our construction requires a lot of effort in order to return as the sources incentives [35].

\section{CONCLUSION}

Throughout the history of rural society has evolved from a primitive village community to the modern, highly developed, rural society. By the first half of the twentieth century in Europe, the peasantry was the largest and most important category of society. Different 
geographical, climatic, economic, historical and other factors have created significant differences, both in Europe thus in Montenegro [36].

Housing satisfies a basic human the need-need for survival, physical protection and security. At the same time, housing allows satisfy many other human psychological, social, economic and cultural needs (reproduction and upbringing of children, work, education, relationships, privacy ...). Quality housing is a requirement for a quality life [37].

Rural architecture and housing in rural settlements of northeastern Montenegro, a reflection of the d cultural, historical and socio-economic conditions, natural and technical developments specified of time. Our research evidence based on similar studies Rodić [38] points out that rural architecture from the nineteenth century is a logical extension the development of residence dating from much earlier times. Simple primitive habitats (dugouts - cave dwellings, semi-dugouts), a more perfect forms of habitat (cottage), proceeded by the developed forms of the house and housing. The traditional way of building a house is being deserted after the Second World War. The old building materials are increasingly give way to the new - brick, tile ... In a constructive regarding, they increasingly resemble a house in urban settlements. Stand out massiveness and size; have been developed not only horizontally but also vertically. In recent times, we find the houses that are significantly different, not only of the houses in the village, but also from the usual method of construction, and cannot be classified by constructive and the spatial solutions in certain types of houses.

Architecture auxiliary buildings of the nineteenth century, certainly reflects the former systems construction of houses. The size and number of such objects is always dependent on the diversity of the economy, household economic status, socio-historical circumstances and geographical environment. In rural areas of the north-eastern Montenegro auxiliary buildings are always located next to the house, in the yard, a part of other household possessions. The cause is probably lack of space, as well as former rural way life, which is conditioned and temporary residence outside the village [38].

\section{References}

[1] Rajović G., Journal of Road and Traffic Engineering 56(2) (2010) 23-29.

[2] Rajović G., Journal of Road and Traffic Engineering 57(1) (2011) 44 -52.

[3] Milovanović O., The roots, Serbian house, 2012, Available from: http://www.forum-srbija.com_(28.05 2013).

[4] Videnović A., Crna Trava, Foundation Andrejević, Beograd, 1996.

[5] Rajović G., Bulatović J., International Letters of Social and Humanistic Sciences 3 (2013) 10-20.

[6] Rajović G., Bulatović J., International Letters of Social and Humanistic Sciences 3 (2013) 37-45.

[7] Rajović G., Bulatović J., International Letters of Social and Humanistic Sciences 4 (2013) 11-21.

[8] Wiggins S., Proctor S., Development policy review 19(4) (2001) 427-436.

[9] Primi A., The costs of distance: rural poverty through a territorial perspective, Master's thesis, University of Pavia, 2002. 
[10] Renkow M., Cities, towns, and the rural non-farm economy, Transforming the Rural Nonfarm Economy: Opportunities and Threats in the Developing World, 2007.

[11] Mohapatra S., Rozelle S., Huang J., Journal of Development Studies 42(6) (2006) 1023-1055.

[12] Lohmann C., Liefner I., Location, non-agricultural employment, and vulnerability to poverty in rural Thailand, Erdkunde, 2009, 141-160.

[13] Rajović G., Geography on the Internet - learning against the limit, Educational Review, Practice and Pedagogy, 04.04, Beograd, 2007.

[14] Simonović Đ., Rural house, PS - 53, Faculty of Architecture, Belgrade, 1980.

[15] Cvijić J., Anthrop geographical problems of the Balkan Peninsula, Serbian ethnographic collection, Book IV, First Department, Village of Serbian lands, Book I, Belgrade, 1902.

[16] Cvijić J., La Peninsule Balkanique, Arnold Colin, Paris, 1918.

[17] Dereko A., Medieval towns in Serbia, Montenegro and Macedonia, "Education", Belgrade, 1950.

[18] Roter-Blagojević M., Milošević G., Jadrešin-Milić R., History of Architecture and settlement 2, 2011, Available from: http://www.arh.bg.ac.rs (29.05 2013).

[19] Traditional architecture, Available from: http://www.belapalanka.org.rs (30.05.2013), 2013.

[20] Vešović J. P., Vasojevića Tribe, "State Printing”, Сарајево, 1935.

[21] Lutovac V. M., Ivangrad (Berane) basin, Geographical institute SASA, book CCLXIX, Belgrade, 1957.

[22] Rajović V., Gnjili Potok and Trešnjevik, "Stupovi - Vasojevići“, Andrijevica, 1995.

[23] Rajović G., Rajović, D., Natural and socio economic characteristics of rural settlements Gnjili Potok, "The Agency PC system ", Belgrade, 2010.

[24] Živković N., Ethnographic reflections in the text - The roots, Serbian house, 2012, Available from: http://www.forum-srbija.com_(31.05 2013).

[25] Kojić B., The development of home and culture of living in the villages of Serbia, Bulletin of the Ethnographic Museum, Book 44, Belgrade, 1980.

[26] Statistical Office of Montenegro, Census of Population and Housing 2003, Podgorica, 2004.

[27] Binford L. R., Journal of Anthropological Research 46(2) (1990) 119-152.

[28] Brown T., Bhatti M., Journal Housing studies 18(4) (2003) 505-515.

[29] Smith C. S., Journal of Anthropological Archaeology 22(2) (2003) 162-189.

[30] Verhage R., Local Policy for Housing Development, Aldershot, Ashgate, 2002.

[31] Li X. M., Liu, W. W., Journal Geographical Research 5 (2006) 003.

[32] Bakić R., Spatial Planning - demographic and geographic aspects, University word, Nikšić, 1998. 
[33] Bulatović J., Rajović G., Journal Protection of Nature 61(1) (2011) 111-128.

[34] Rajović G., Montenegrin immigrants in Denmark, "The Agency PC system", Belgrade, 2011.

[35] Petrović Z., The old Serbian house as a building encouragement, Construction of books, Belgrade, 1985.

[36] Todorović M., Rural society and rural geography in the past and the future, Geographical Institute "Jovan Cvijić” SASA, Belgrade, 2007, 45-53.

[37] Petovar K., Housing as a human right, Faculty of Architecture, Belgrade, Available from: http://www.arh.bg.ac.rs_(31.05 2013).

[38] Rodić Z., Bulletin of the Ethnographic Museum 74(1) (2010) 109-142. 